\title{
4. 日本から発信するIBD診療の新たなエビデンス
}

東京医科歯科大学消化器内科

渡辺 守

Key words : 潰瘍性大腸炎, Crohn病, 炎症性腸疾患, 診断, 治療

はじめに

炎症性腸疾患 (inflammatory bowel disease : IBD)である，潰瘍性大腸炎及びCrohn病は，こ れまで日本においては比較的稀な疾患と考えら れ, 厚生労働省 特定疾患治療研究事業に指定さ れた「指定難病」に指定されている。しかしな がら, 近年, 患者数は増加の一途をたどり, 平 成 26 年度衛生行政報告において, 潰瘍性大腸炎 181,560 人, Crohn病 42,397 人と合わせて 22 万人 となり, 306 ある難病のなかでも一番患者数が多 くなった（図 1). 特に潰瘍性大腸炎患者数は, 米国に続いて世界第 2 位となり，本疾患を専門 としない医師も患者を診る機会が多くなった.

また, 治療に扔いても, 生物学的製剂の使用率 が世界一になった。ささに, IBDの基礎研究にお いて, 日本は数多くの優れた成果を挙げており, 世界的にもその業績は高い評価を受けてきた。

この 10 年で, 日本は世界のIBD診療のまさに中 心となるべき国となった。しかしながら，現実 はどうであろうか. IBDの臨床研究に関しては全 くの後進国であり, 一時期, 欧米おいては, 韓 国の方が高い評価を受けるという驚くべき状態 に陥った。しかしながら，2013 年頃より，日本 から次々に世界のIBDガイドラインを書き換える ような優れた臨床研究が報告されてきた。

略歴は 138 頁に記載
1. 炎症性腸疾患の診断に関する新しい展開

この 4 年間で, 日本からの診断に関する重要 な論文がimpact factor 10 以上の杂誌に 5 報掲載 されている.まず,我々の教室から報告したCrohn 病に対するMRE（MR enterography）と小腸内 視鏡所見比較の論文である (図 2)。これまで, Crohn病の小腸病変に関しては小腸造影, $\mathrm{CT}$ (computed tomography), MRI (magnetic resonance imaging) で評価されてきたが，この研究 は世界で初めて内視鏡と欧米で一般化している MRI所見を同一患者で直接比較した試験として 高く評価された ${ }^{1)}$ 。この研究は日本で開発され, 現在は日本でしか汎用されていない小腸内視鏡 を最大限に活用したオリジナリティーの高い研 究である.さらに, 前向き試験でMRE所見がそ の後の再燃や手術, 入院等の予後を予測可能で あることを初めて示した論文も発表され2 ${ }^{2}$, 小腸 の病変評価及び予後評価において, 小腸バルー ン内視鏡とMRIは同等であることを示し，診断 に重要な知見を与えた. 2 つ目は, 潰瘍性大腸炎 の病状把握に対して, 便ヒトへモグロビン定量 fecal immunochemical test (FIT) が有用である とする論文である ${ }^{3)}$.このFIT検査は簡便であり， 外来受診日に結果が出るのみならず，内視鏡に よる粘膜治癒と相関しており，実臨床に大変意 義のある検査として注目されている。ささらに， 海外で開発され, IBD, 特に潰瘍性大腸炎のバイ 


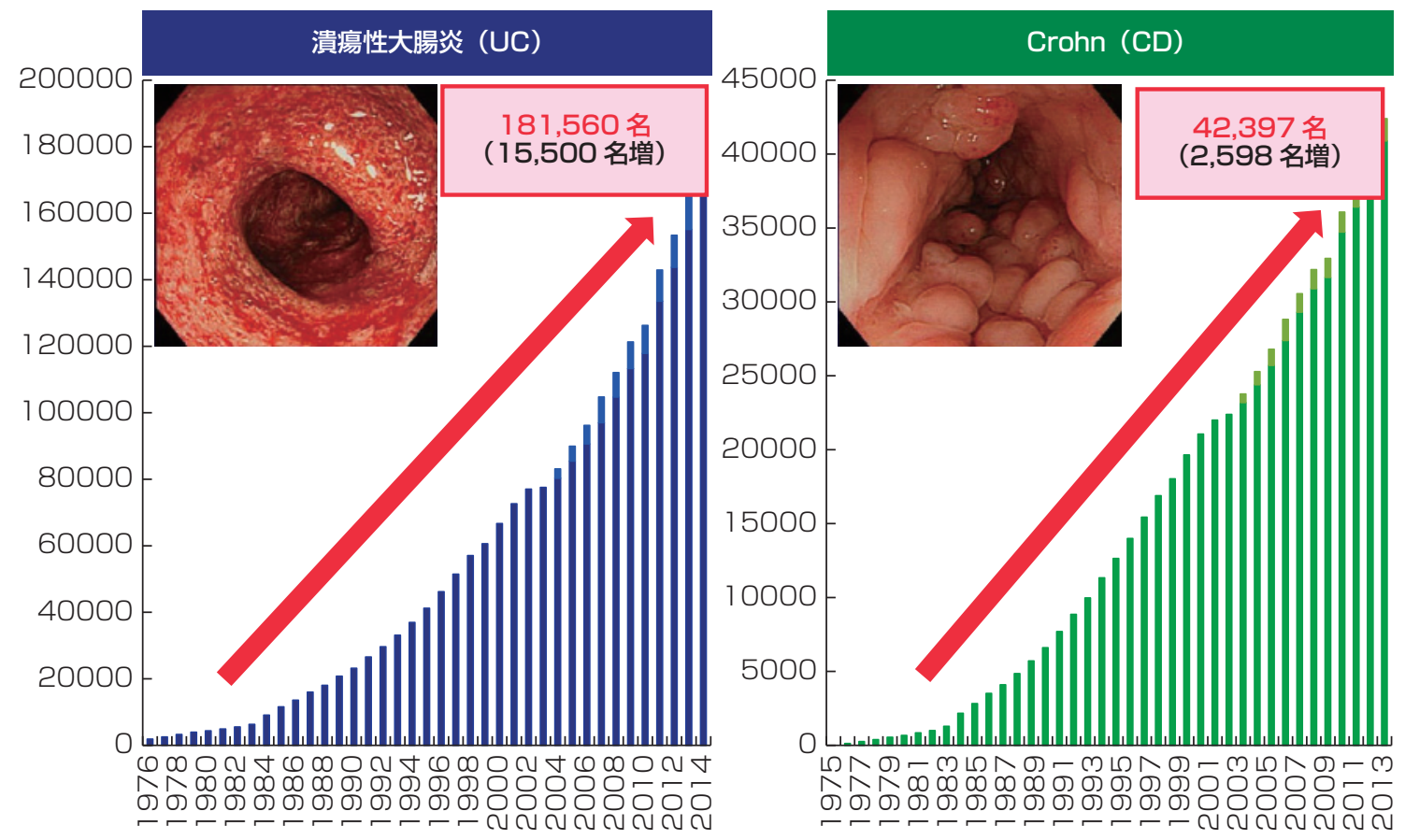

図 1. 日本において咨症性腸疾患は急増している（厚生労働省 : 平成 26 年度衛生行政報告）

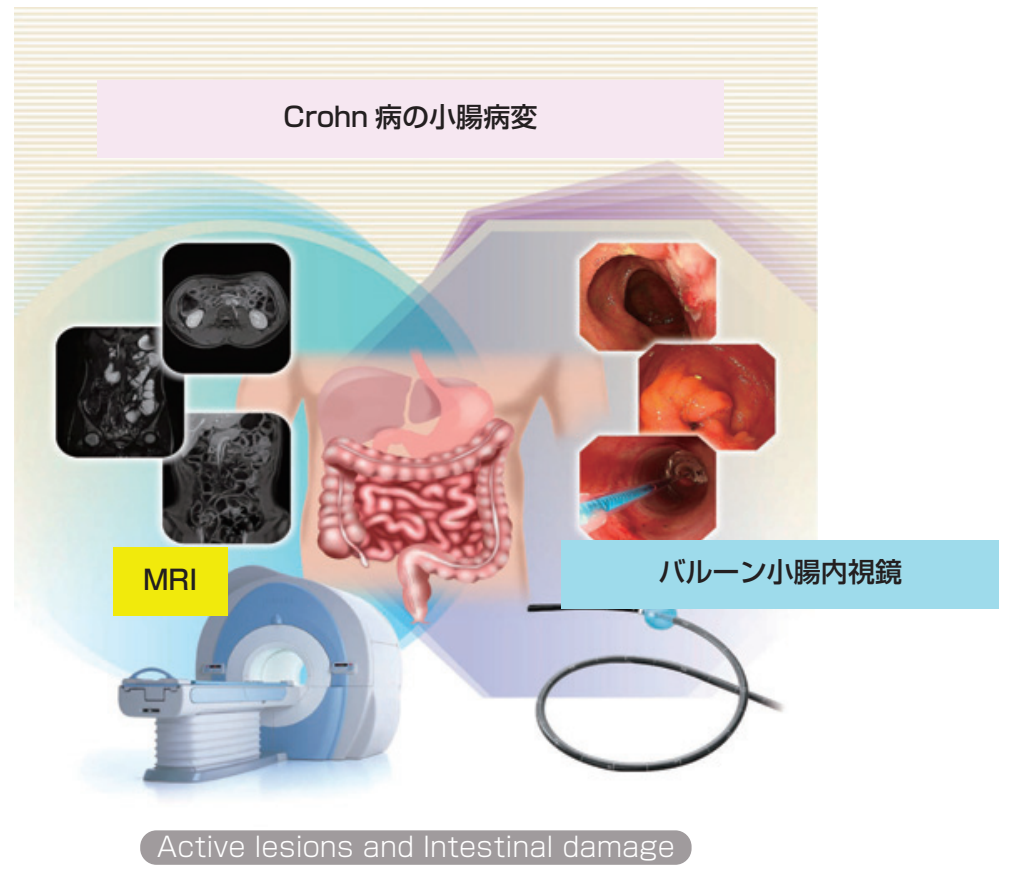

図 2. Crohn病小腸病変における MRI所見とバルーン小腸内視鏡所見の直接比較 
オマーカーとして注目されているカルプロテク チン測定とFIT検査がほぼ同程度の感度・特異度 を示すばかりでなく, 内視鏡による完全な粘膜 治癒を評価する指標としてはむしろFIT検査が優 れているという結果も出ており ${ }^{4)}$, 今後, 海外で も利用が拡大する検査として注目される. 3 つ目 は, 厚労省難病班会議主導で行われた潰瘍性大 腸炎に対する大腸がんサーベイランスにおける Target生検とRandom生検の前向き比較試験で ある ${ }^{5}$. 潰瘍性大腸炎に発生する大腸がんは見つ けにくいばかりでなく, 進行が速く, 転移を来 たしやすい悪性形質を有するため, サーベイラ ンスは不可欠である，海外においては, random に 32 カ所の生検を行うことが推奨されてきたが, 日本で行われてきた内視鏡所見によるtarget生検 + 少数random生検は同等であることが初めて示 され，今後，ガイドラインの改訂があるものと 思われる。

さらに, 今後 5 年間, 治療法の選択や工夫に 役立つ情報に関して, 厚生労働科学研究費補助 金 難治性疾患等政策研究事業「難治性腸管障害 に関する調査研究」班主導で行われた多くの臨 床研究が発表されることが期待されている. Crohn病に対するDIAMOND試験, CERISIER 試験, 潰瘍性大腸炎に対するHAYABUSA試験, ACTIVE試験をはじめとして, 多施設共同試験 が期待されるほどのスピード感ではないが進ん でおり，欧米のコンセンサスを変えるエビデン スとなるような研究成果を期待している. なか でも, Crohn病治療におけるヒト型抗TNF（tumor necrosis factor) $-\alpha$ 抗体製剤アダリムマブ使 用の際に免疫調整薬を併用するべきかどうかに ついては世界的にエビデンスがなかったが, 厚 労省班会議を中心にオールジャパン体制で行わ れたDIAMOND試験において, 生物学的製剤ナ イーブなCrohn病においては, 52 週の臨床的寛 解率ではアダリムマブ単独治療群とチオプリン 製剤併用群との間で有意差がないことが示され た.この結果は, 先行したインフリキシマブに
おけるSONIC試験の結果と異なるものであり， 世界的に注目された。ささらに本試験のサブ解 析の結果として, チオプリン製剤内服と抗製剂 抗体産生との関係が報告された。引き続き，内 視鏡的寬解率から見た検討, 日本人患者におけ るチオプリン製剂副作用リスク等, サブ解析が 行われている. DIAMOND試験は世界的にも有 名な試験になっており, 今後もこのような体制 での試験が次々と日本から発信されることが期 待されている.

\section{2. 日本発の新規治療法を目指す試み}

日本からのIBD治療に関する論文は, 2009 年に潰瘍性大腸炎に対するタクロリムス治療有 効性を示す論文が出て以降, 優れた研究報告は 発表されておらず, 新しい治療を世界に提案で きない状態が 10 年近く続いた. 一方, 海外にお いては,この数年で, 生物学的製剤抗TNF- $\alpha$ 抗体製凨の成功を基盤に, IBDに対して, 生物学 的製剂を主体とする免疫異常を制御する数々の 治療法が開発されてきた。サイトカインをター ゲットとする治療法, 接着分子をターゲットと する治療法が開発され, 現在, いくつかの臨床 試験が精力的に進められている ${ }^{2)}$. その多くは欧 米からの薬剮である。このまま, 日本は海外に 依存し続けてよいのであろうかという議論が出 された。

しかしながら, 日本でもいくつかの新しいIBD 治療の試みは始まっている。 その 1 つは, 本来 は生物製剤ほど効果がなくても安価な低分子化 合物（経口薬）が開発されるべきであるという コンセプトのもと,「日本オリジナル」の接着分 子に対する経口低分子化合物が開発され，2014 年 5 月のDDW (Digestive Disease Week, 米国 消化器病週間)で, ASGE/AGA Presidential Plenary Sessionという最も大きなセッションに選ば れ，論文化 ${ }^{6)}$ れて注目された，2つ目は，2017 年, 漢方薬の成分である青黛indigo naturalisの潰 瘍性大腸炎に対する多施設共同研究の結果が報 


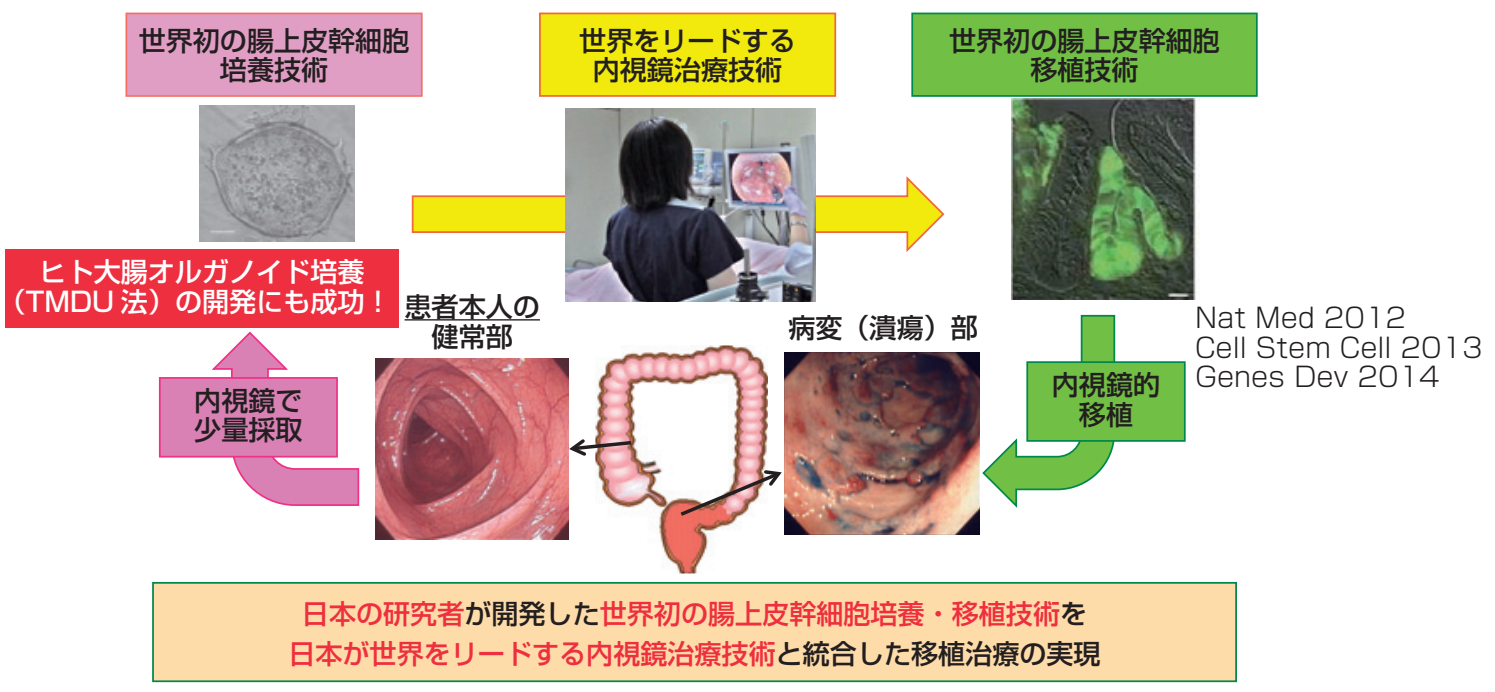

図 3.内視鏡で採取したヒト組織から，腸上皮幹細胞移植治療へ

告され7), 有効性が注目されている。また, Crohn 病の狭窄病変に対する内視鏡的拡張術の多施設 共同研究が進められており, 意義深い報告にな ることが期待される

さらに，我々のグループで開発中の腸上皮幹 細胞を使用した粘膜再生治療 (adult tissue stem cell therapy) (図 3) は, AMED (Japan Agency for Medical Research and Development) 再生医 療実現拠点ネットワークプログラム拠点Bに選ば れ, IBDに対する根治療法として世界的にも注目 度が高い. 我々が開発した世界初の大腸上皮幹 細胞培養技術と移植技術の基礎研究8 11) 基盤に して，日本が世界をリードする内視鏡治療技術 とを統合したfirst-in-man治療が 2018 年度にも始 まろうとしており，注目されている.

おわりに

IBDにおいては新しい薬剤が開発されにくい今 後 5 年間が, 日本が世界をリードするチャンス である。日本オリジナルの治療法の開発は多く の製薬企業で開始されており, 特に経口の低分 子化合物は大いに期待される.また, 我々はIBD に対する新しい概念での再生医療を AMED再生 医療実現拠点ネットワークプログラムにおける
拠点Bとして進めており，1〜2 年でfirst-in-man を目指している. 日本のIBD専門医はこの 5 年間 がIBD診療の本当の正念場であることを十分認識 し，新たなエビデンスを作っていく覚悟を持つ ことが必要である.今後のIBD治療はさらなる高 い目標の達成が求められることが予想され, 完 全治癒が期待できる可能性のある病気であるこ とを理解していただきたい.

\section{文献}

1) Takenaka $K$, et al : Comparison of Magnetic resonance and balloon enteroscopic examination of the small intestine in patients with Crohn's disease. Gastroenterology $147: 334-342,2014$.

2) Takenaka K, et al:Utility of magnetic resonance enterography for small bowel endoscopic healing in patients with Crohn's disease. Am J Gastroenterol 2017 (in press).

3) Nakarai A, et al : Evaluation of mucosal healing of ulcerative colitis by a quantitative fecal immunochemical test. Am J Gastroenterol 108: 83-89, 2013.

4) Takashima S, et al : Evaluation of Mucosal Healing in Ulcerative Colitis by Fecal Calprotectin Vs. Fecal Immunochemical Test. Am J Gastroenterol 110 : 873-880, 2015.

5) Watanabe $T$, et al : Comparison of targeted vs random biopsies for surveillance of ulcerative colitis-associated colorectal cancer. Gastroenterology 151 : 1122-1130, 2016.

6) Yoshimura N, et al : Safety and Efficacy of AJM300, an Oral Antagonist of $\alpha 4$ Integrin, in Induction Therapy for Patients with Active Ulcerative Colitis. Gastroenterol- 
ogy 149 : 1775-1783, 2015.

7) Naganuma M, et al : Efficacy of indigo naturalis in a multicenter randomized controlled trial of patients with ulcerative colitis. Gastroenterology 2017 (on line).

8) Yui S, et al : Functional engraftment of colon epithelium expanded in vitro from a single adult $\mathrm{Lgr}^{+}$stem cell. Nat Med 18:618-623, 2012.

9) Fordham RP, et al: Transplantation of expanded fetal intestinal progenitors contributes to colon regeneration af- ter injury. Cell Stem Cell 13 : 734-744, 2013.

10) Fukuda $M$, et al: Small intestinal stem cell identity is maintained with functional paneth cells in heterotopically grafted epithelium onto the colon. Genes Dev 28: 1752-1757, 2014.

11) Yui S, et al:Cellular reprogramming links environmental signaling to YAP/TAZ and tissue regeneration. Cell Stem Cell 2017 (on line). 